\begin{tabular}{|l|l|l|l|l|} 
maq_12004 maq2008.cls & \multicolumn{5}{l}{ November 16, 2012 $11: 2$} \\
\hline \multirow{2}{*}{ aptara } & MAQ & maq_12004 & Dispatch: November 16, 2012 & CE: N/A \\
\cline { 2 - 6 } & Journal & MSP No. & No. of pages: 15 & PE: Sarah McKay \\
\hline
\end{tabular}

Christopher Davis

School of Oriental and African Studies (SOAS)

University of London

\title{
What is Life Worth?
}

A Rough Guide to Valuation

In this speculative article, the aim is to elaborate a definition of life that is not biological, and a valuation of it that is not commodified. This is undertaken by the development of an understanding of death as a process which is embedded in the life of a community. The idea is that we can best understand what life is worth by first understanding what death means. [death, life, humanitarian, mortality, utopian]

I think about my education sometimes. I went to the University of Chicago for a while after the Second World War. I was a student in the Department of Anthropology. At that time, they were teaching that there was absolutely no difference between anybody. They may be teaching that still.

Another thing they taught was that nobody was ridiculous or bad or disgusting. Shortly before my father died, he said to me, "You know-you never wrote a story with a villain in it."

I told him that was one of the things I learned in college after the war. -Kurt Vonnegut, Slanghterhouse Five

Archimedes, who was a kinsman and friend of King Hiero, wrote to him that with any given force it was possible to move any given weight; and emboldened, as we are told, by the strength of his demonstration, he declared that, if there were another Earth, and he could go to it, he could move this one.

-Plutarch, Lives

Give Me an Ethnography and I Will Move the World

Although much use is currently made of his work defining the biopolitical, it is with Foucault's earlier work on knowledge systems that I would like to begin. I choose to go back to his praise of our discipline at the close of The Order of Things because there he accords ethnology the status of "counterscience" among the human sciences. With psychoanalysis, ethnology is a method of examining thought by thinking in terms of thought's limits; those boundaries that not only characterize it as specific to a place and time (however universalist its claims) but

MEDICAL ANTHROPOLOGY QUARTERLY, Vol. 26, Issue 4, pp. 503-517, ISSN 07455194, online ISSN 1548-1387. ( 2012 by the American Anthropological Association. All rights reserved. DOI: $10.1111 / \mathrm{maq} .12004$ 
also, and in the same process, show that there always remains something "other"an unthought-embedded within it.

Psychoanalysis and ethnology occupy a privileged position in our knowledge-not because they have established the foundations of their positivity better than any other human science, and at last accomplished the old attempt to be truly scientific; but, rather, because, on the confines of all the branches of knowledge investigating man, they form an undoubted and inexhaustible treasure-hoard of experiences and concepts, and above all a perpetual principle of dissatisfaction, of calling into question, of criticism and contestation of what may seem, in other respects, to be established.

[Foucault 1970:373]

This topos is separated by the merest of dotted lines from the terrain occupied by Lévi-Strauss in his Tristes Tropiques. There, in chapter 38, entitled "A Little Glass of Rum," Lévi-Strauss presents us with the central tasks of anthropology: First, getting to know other societies in order to detach ourselves from our own (ours "is the only one from which we have a duty to free ourselves: we are, by definition, free in relation to the others"). Second,

using all societies-without adopting features from any one of them-[we are] to elucidate principles of social life that we can apply in reforming our own customs and not those of foreign societies ... the society we belong to is the only society we are in a position to transform without any risk of destroying it, since the changes, being introduced by us, are coming from within the society itself. [Lévi-Strauss 1974]

His point is that "nothing is settled; everything can still be altered. What was done but turned out wrong can be done again" (Lévi-Strauss 1974:393).

More modest than Archimedes, but still Archimedean in intent, each man suggests that ethnography's aim is to find or build another Earth for us to stand upon, and that ethnology provides the lever by means of which we can move this one. (Latour [1990] would argue that the very practice of ethnographic observationuniting experience with experiment-makes this less impossible than it might initially seem.) Indeed, in the days in which "others" were exotic, and regarded as somehow more "natural," the social role of anthropology was precisely to represent (especially. I would say in a mid-century U.S. context) utopic possibilities. We could look, say, at the way people came of age in Samoa (Mead 1928) to discover another way we could also be. Anthropologists Margaret Mead and Ashley Montague were public intellectuals.

When the "otherness" of "others" became a function of our own myopia or of our method (Clifford and Marcus 1986) —and, beyond that, when globalization brought us all into a single economic and political social field-not only did we cease to be engaged by the "strange," we also ceased, or so it seems, to be engaged by utopia. We focused instead on contradictions in circumstances and pathologies of power (cf. Farmer 2005; Scheper-Hughes 1992). The justice-seeking, equalizing tendencies fundamental to the ethnographic gesture turned from explanation to 
social critique, and there was a corresponding overall decline in our interest in celebrating diverse logics for their own sakes. Indeed, one could argue that this progress of our normal professional motives-and even this continuation of our normal professional methods-has led us to be mainly concerned with the dystopic.

Given the significant and, it seems, increasing levels of social inequality in the world, this is far from inappropriate. Yet to give this approach pride of place seems also to mean confinement to a single underlying logic, a single overall world view. It is as though we have integrated other people, without equally integrating other ways of thinking. What I would like to do is find a way to get us back to an appreciation of our responsibility for utopic possibilities (Auge 1998, 1999).

Our current area of study is the social field, rather than the life of a group, and our method is situational analysis (Gluckman 1958). We work on a particular problem, rather than on "culture" as some sort of abstracted whole. This is a more realistic representation of our observational approach anyway, one already established by the Manchester School (Werbner 1990) and having the virtue of being applicable anywhere (Frankenberg 1981). Our proper study is of human originality (Guyer 1999), and our aim, at least in part, is the enhancement of logodiversity.

The challenge for ethnology will be to recuperate our former way of fabricating and making available a way of seeing things otherwise, of looking at the world from an angle that at first seems slightly awry. When we worked with other groups, "the native's point of view" was otherwise enough in itself. One had mainly to explore and explain its rationality. The unified world, with our focus on social fields, demands not only that we engage ethnologically from field to field but also that we do so with greater imaginative impertinence than before. (Lévi-Strauss's marvelous comparison of cannibalism and the prison system as a way of discussing savagery and society comes to mind as a possible set of the bar [1974:386-389].) This maintains our commitment to labor beyond the shadow of "primitive mentality" even as we endeavor to contribute to an undoubted and inexhaustible treasure hoard of experiences and concepts.

This is also a way of saying that ethnography's cheek will often be to offer a qualitative answer to a quantitative question. That at least is what I'm attempting to do here; an essay in the strict sense of the term, in response to the question "What is life worth?"

\section{Food for Worms}

The irony. Having just attempted to focus our attention on the utopic, I am asking that we think about the morbid, starting with necrosis and gangrene http://en. wikipedia.org/wiki/Necrosis (accessed Oct. 26, 2012) and http://en.wikipedia. org/wiki/Gangrene (accessed Oct. 26, 2012) I want to start with them because they are death in life and thus show better than would any more abstract consideration the relationship between the two. Thinking of them in this, organism-centric, way allows us to observe that death is something life does in response to a certain type of insult or set of events or circumstances. Thus, we shouldn't oppose life to death so much as to non-life, a point to which I'll return in a minute.

Taking this perspective is a way of getting me, of getting us, to be more conscious of what it is we mean when we talk about life-that is, to understand life in terms of 
vitalism or vitality. The sense I have often had is that even when we talk about life and about the body, in our discussions these still maintain a thing-like or mechanistic quality. We lose the sense of life as a precarious, somewhat unstable process, but one that is, nevertheless interested in staying alive and that therefore has a relationship to the environment that is already charged, and value-laden. This, of course, is from Georges Canguilhem's brilliant exploration of the normal and the pathological (1989). Once we see life itself as interested, we establish at least three possibilities for our ways of thinking.

One way is to make human life continuous with other life, including the lives of the microbes that would be interested in the opportunity afforded them by necrosis. From the perspective of "life itself" this would be a mere shift from viewing life as it is valued by one organism to including the perspective on that life taken by its various opportunistic others. This is a specification exemplified by the work of Stelarc (http://www.stelarc.va.com.au/ accessed Oct. 26, 2012), particularly his "Ear on Arm" project and the "Partial Head" project.

Stelarc is an Australian born artist whose current projects are based on the idea that the body is obsolete and that all of its functions will eventually come to be replaced by technologies that themselves can be repaired and maintained on a continuous basis. His view is that we live in an age of circulating flesh, of fractal flesh in which organs can also live without bodies. The theory of his practice is posted on his website; his practice is inscribed in his own flesh.

I just want to borrow a few points from his experience. When we look at his acknowledgements for the two projects in question, we see that, for the moment at least, the postobsolete body takes more people and money to run than does the current, obsolete, intermediate technology type body we have now. Such is often the case with new technologies and this is something of a sidebar observation.

More to the point, in each of the examples above, the purism of Stelarc's utopic or theoretical vision was disturbed or interrupted by life itself. The initial implant of the ear in the arm resulted in cell death (necessitating surgery) and infection. The partial head (which involved the use of live cells in a growth medium) became contaminated after a week and had to be preserved in formaldehyde. So we see that there is a sort of incontinence inherent to vitality, one that is temporarily held in check by the skin (or membrane if you are a cell)-itself an outcome or function of the vitality within. On this view, life is continuous and death encompassed by it.

Another possibility is to think about how life is continuous with the non-life that exists or can exist within it. Here, just as two examples, I am thinking of paracetamol poisoning and of the actions of prions (Ridley and Baker 1998). Descriptions of these can be found here: http://www.patient.co.uk/doctor/Paracetamol-Poisoning.htm (accessed Oct. 27, 2012) here: http://en.wikipedia.org/wiki/Paracetamol_toxicity (accessed Oct. 27, 2012) and here: http://www.bbc.co.uk/dna/h2g2/A531776 (accessed Oct. 27, 2012).

In each instance, it is the actions of molecules-objects not themselves alive and so indifferent to the interests of the life form of which they are a part-which make the pathology.

Finally, the vitalist perspective helps us to recognize in all forms of life a capacity for responsiveness, which allows them to approach the minimum threshold of the status of subject. This quality is what permits nonhuman subjects to serve as 
"witnesses" to the validity of human experiments (Haraway 1997). The idea of the body itself as meeting this minimum I have borrowed from the vernacular medical system practiced by people in Mpala in the Democratic Republic of the Congo (Davis 2000). There, the body, and other vital processes (such as beer brewing) can be made to serve an oracular function. In each of these cases vitality is provided with an apparatus that allows it to speak (Latour 1983, 1990).

This draws our attention to the respect in which all medical interventions might also be seen as forms of dialogue, at best, or, at the very least, as forms of experimental intervention, with life itself as the respondent or interlocutor. In this sense, to reason anthropologically from medical practice-taking it as a model and a site of knowledge production-is to think in terms of an anthropology of medicine more than a medical anthropology (which seems to presume that we know what medicine is). So, with this blurring of boundaries between life and death made thinkable for our purposes (and within the biomedical episteme), we can perhaps begin to look at what life is worth by thinking about what death means.

\section{Mortality and Moral Community}

Normal Mortality, So to Speak

Death

In the opening paragraph to their Celebrations of Life, Metcalf and Huntington observe that nothing could be more universal than death, and yet nothing can match the wide variety of practices by which human beings engage with the decomposition of the body (Metcalf and Huntington 1991), a decomposition that is in fact the appropriation of one life form by others. The work of Cedric Mims provides a comprehensive survey of what happens when we die (Mims 1998). At the level of the social, there is, as Hertz noted, a correspondence between the decay of the corpse as an object, and the reconstruction of the person beyond it (Hertz et al. 1960). That mortuary ceremonies are intended to reweave the social fabric is an anthropological commonplace.

Nevertheless, reminding ourselves of the very physical engagement people have had with death is meant to serve, in turn, as a gateway to considering the productivity of mortality in social life; its use and usefulness in the production of moral community. Beyond mortuary practices themselves, there are the issues of descent and inheritance.

The Central African practice of “perpetual kinship" (Cunnison 1951, 1956, 1959), for example, means that there is an exchange relationship between sublineages or lineage segments, which is such that the name, spouse, and indeed the life of a deceased person from one segment is inherited by someone nominated from the other. By this means, a living individual may accumulate a number of names across her or his lifetime. Kinship terms of reference are changed accordingly, and in genealogies only one name will be given even though that identity may have been occupied by a number of different people. (This makes for funny anthropological experiences.)

It's not so much that "perpetual kinship" creates stasis despite death (a sort of old-school structural-functional way of looking at things), as that death is part of how microhistory is made and marked at the level of life as lived. It is an honor to 
be named as heir and the relationship between sublineages is such that people are almost on the point of forgetting how they are actually related (Davis 2000:214.) Death is thus the way in which the living social order moves itself through time. Only the oldest members of the groups can recall the name of the ancestress who unites them, so memory itself exists at the edge of its own perishing; the point in the system's vital dehiscence at which one definitively becomes two, relation nonrelation.

The differences in perspective are like the contrasts marked out by de Certeau when he opposes the experience of viewing lower Manhattan from the top of the World Trade Center with the experience of actually walking in the city (1984). One view gives the city as coherent and seemingly stable, the other an understanding of the city as the multitude of irregular trajectories and memories that are created as people go about their everyday lives. In kinship and inheritance, death and life are interwoven in such a way that death or the possibility of death-and indeed the ultimate certainty of death-are what make possible moral community and its production over time. (Here I am implying that the very concept of "reproduction" is a mistake. There is only production. Every birth is a perilous passage for both mother and infant. Every face coming into the world has never before been seen.)

The constant awareness of death (including its social correlatives, i.e., inattentiveness to and disregard for death) underpins moral community as mediated by therapeutic and divinatory practices. I am thinking here of the role of illness as something that not only prompts accusation but also signifies mortality in a way that makes clinging to grievances seem selfish, self-regarding and nonsensical. In Turner's lovely study of an Ndembu doctor in his practice, Kamahasanyi's suffering is exacerbated by the fact that his relatives don't seem to take it seriously even though they are morally obliged to treat it as such (1967). In my own work, knowing one would die or would someday need help was meant to have a moderating effect on behavior (Davis 2000) even though it often didn't.

Here, there is also something of an overlap. In the circumstances of problematic illness, there is a shared questioning across cultures, locations, social fields. There is an interest in producing knowledge that links anthropologists and those with whom they study life. In the context of medicine, life is a problem for knowledge. Illness can be problematic, and the shared question in the face of it is "What is to be done?"

\section{Pathological Mortality, So to Speak}

The idea of "wasted life" (Fassin 2009) marks the boundary between normal mortality and its opposite. Like all boundaries between normal and pathological, it is moving (Canguilhem 1989). With the perception of life as wasted, there is not so much the question of "what is to be done?" as there is the exhortation of "something must be done!" It indicates a state of extremity that can be partly due to the sheer quantity of mortality-the numbers-but also due to the type of mortality; the sense that a capability or talent for life has been interrupted or even that the person's (or the organism's) own death has been stolen. In this, we might say we see the frontiers of moral community as inscribed in mortality. 
The exhortation points to the frontier itself, attempting to force a community to look beyond its comfortably familiar interior and to see the violence of its own foundation in the process. Such would be the effort of Povinelli's piece, "The child in the broomcloset," which seeks to draw moral attention to the link between the conditions of Aboriginal Australians and the prosperity of the settler community (2009). However, from a properly ethnological perspective, the remedy for which the exhortation calls can't be predetermined.

The response to "wasted life" could be remediation via redistribution of resources, as is suggested by Farmer, Scheper-Hughes and many others. Here the intention is clearly to improve the action of moral community, to better protect those left on its economic and political margins. It could be retaliation, as we see in the work of Ashforth (2005) and Godoy (2002, 2006) where the response to the waste of life is vigilantism. (Human beings are never more inclined to be barbarous than when they think themselves confronted by barbarity.) It could, for that matter, be extermination, as in the concept of "life unworthy of life" (Agamben 1998; Burleigh 1994), in the face of which death can be construed as a kind of deliverance.

\section{Lethality and Moral Community}

What I'm trying to do at this point is to consider the ethical or moral parameters within which quantification takes place or makes sense because these parameters will condition what is "too much" mortality or "too little" vitality. This is another way of thinking about what life is worth by considering what death means, bearing in mind that the one quantity we will never find is "enough."

I am pondering lethality as a kind of hinge on which these parameters turn-that is as a social form by which they can be changed, moved, reconstituted. On this view, lethality, and narratives from or of it, can be quite directly transformative of the boundaries of moral community in a way other types of mortality are not. One could think of it as having alchemical properties-that is as being socially "alchemical" (Davis 1993, 2002; Jacobson 2006; Williams 1991).

It would be good to start by distinguishing lethality from other related terms occupying the same or similar semantic terrain. As far as I have been able to explore them, rough distinctions would be:

Mortal-death from within, the vulnerabilities of the flesh

Fatal-death from without-accident, blow, etc.,

Deadly-likely to cause death, but not necessarily designed to do so (as in the way a wrench or hammer can be a deadly weapon)

Lethal-certain to cause death, though death may not always result (a gun is an obvious example of a lethal weapon).

So, this particular feature of the lethal - this point about certainty-is what makes it an alchemical value changer. Thought and prospection are involved; intention plays some part in the process. This certainty is what locates lethality right at the heart of our condition as empathic predators, and I would say that recognizing this condition is fundamental to any comprehensive understanding of human being. It 
is our (definite) curse and our (potential) redemption as creatures-the foundation of our basic dilemma as social actors.

We know things will kill and we know torture hurts because we're empathic, but because we're predacious we do them anyway. In the doing, we attempt to protect our capacity for empathy by defining our "victims" as those deserving of the treatment we inflict on them. In which sense, one can say that lethal behavior is always in defense of something, even though, in so saying, we are clearly marking a broad circle of comprehension. This is not comfortable for us as citizens, but it is consistent with our professional obligation as understanders of human being.

Going back to the "wasted life" section above, then, it is this characteristic that makes us, as human beings, wish to respond to the "life wasters" with death, whether through mob violence, eugenicist "cleansing" of the body politic, or state homicide (Sarat 2001). Yet built into the witnessing, the narration of this very process, is the possible evocation of pity for the killed. This comes up in the commentaries reported by Godoy (2002), and in histories of execution at the points where executions ceased being public at least in part because they were no longer considered to be edifying. There was the risk of the public sympathizing with the executed, rather than being in awe of the state power authorizing the execution (Foucault 1979; Le Graw and Grodin 2002).

Here, I just want to make the point that because of this aporia-this basic contradiction in our being-lethality and pity are twinned. One evokes and also refutes the other. This can make casualties of perpetrators as with post traumatic stress disorder (Gutmann and Lutz 2009; Shay 1994; Young 1995) Or, in another of those fine ironies that characterize human being, the introduction of a "humane" form of killing can increase the use of killing as method of punishment. Le Graw and Grodin (2002) report that the introduction of lethal injection lead to an increase in the number of executions, while descriptions of a "botched" execution made visible the suffering of the man condemned (Mackey 2009) and led to the postponement of two other executions pending the revision of lethal injection procedures (Driehaus 2009).

This labile twinship between lethality and pity is all the more alchemical when the lethal behavior is self-destructive, but also altruistic or self-sacrificial. Two classic accession attempts come to mind. Each involves the efforts of a group to accede to the full dignity of citizenship and social equality through a willingness to kill and be killed on behalf of the state, to make the ultimate sacrifice as politicians would say (see Taussig-Rubbo 2009a, 2009b). These are the African American Massachusetts 54th during the U.S. Civil War (http://en.wikipedia. org/wiki/54th_Massachusetts_Volunteer_Infantry, accessed Oct.27, 2012) who preferred to fight for no salary, rather than to accept the debased terms on which their participation in the Union Army was based. The 110th Battalion of the 442nd Regimental Combat Team made up of Japanese Americans during World War II (Advertiser 2007), all of whom had volunteered directly from internment camps. Although much more has also been required, self-sacrifice is an important means of having one's condition recognized and one's intelligence respected, and the politics of lethal behavior is not confined to combat situations.

An article in the New York Times has informed us that Hmong shamans are now allowed to practice in hospitals in California (Brown 2009). A certification 
system and set of protocols for shamanic practice were adopted after it became clear that people were risking or sacrificing their lives, in biomedical terms, because of the institutionalized incompatibility between hospital and shamanic treatment. Respectful attention was drawn to the dilemmas of this cultural difference via the publication of a popular book centering on the lethal outcome of misunderstanding over medical treatment (Fadiman 1997). It is, of course, also worth noting that the Hmong community came to be in California through a type of self-sacrifice similar to the ones noted above-in this instance, loyalty to the United States during the war in Vietnam.

In a final example, we can consider the consultation about and change to U.K. guidelines concerning the prosecution of those who help relatives seeking assisted suicide in Switzerland. The lawsuit brought by Debbie Purdy highlighted the complexities of altruistic lethality (Davies 2009; Topping 2009) Although assisting or encouraging anyone to commit suicide remains a crime (carrying a penalty of up to 14 years in prison), in the aftermath of Purdy's legal victory (and in view of the $100+$ cases of people seeking assisted suicide with no actual prosecution of their relatives), the Director of Public Prosecutions issued guidelines outlining conditions under which prosecutions are and are not likely to be brought. From the perspective of this discussion, the lethal behavior of supporting relatives has contributed to a change in the position of the state and community with regard to this mortal, moral dilemma.

So, in these examples, we see the crude outlines of the formula for social changefor the movement of moral boundaries via the alchemy of lethality.

There needs to be numbers of people engaging in the practice-not themselves as weapons or as means of destruction, but as actors protecting or respecting a principle.

The choice has to be clearly connected to a particular, comprehensive and rational end.

It has to be made visible- - has to be made to emerge from the local and from the noise of the everyday by some means of publicity or other.

These together create a condition or situation on the basis of which a case can be brought-and/or changes to policy made with the help of people not necessarily immediately affected

This set of criteria and sequence of events resembles that by which actions of militant nonviolence can lead to social change. There are comparable social costs (deaths, lengthy struggle), as well as comparable vulnerabilities (uncertainty of outcomes, perverse, or unintended consequences). The relationship between lethality and moral community is, of course, always political.

\section{Reconstructing Charity}

To bring us back to our opening discussion, what I'm getting at is that, at this moment, the utopic can't be a pure, ahistoric form. It can't be set in pure principle. It can't be whole, complete, or even enduring, but must always include fragmentation, dirt, death, mess. This is not where I wanted my thinking to take me. 
I had wanted to make this into an argument about diversities of logic; an argument, that is, in favor of continuing respect for other modes of understanding vitality-modes other than the biological. I wanted to use the analysis here to develop a common ground on which multiple modes could be compared. The point would have been, therefore, to restore to anthropology some of its function of allowing not only other voices to be heard, but also other understandings of life to be accepted in and for the present. The aim was to restore to others a respect for their thinking about how best to live and die.

This was to say that we should not in an unthinking way continue to accept the consolations of the laboratory; the promissory note that there will one day be the thing that will redeem them all—a vaccine or something similar, so that we are helpful, but exempt from mess. This would have been an extension of an earlier line of thinking (Davis 2007). It's not what has emerged from this one.

However, I do find that I am able to argue that mess is inevitable, and that theorizing from mess makes us start (and possibility end) in potentially ugly mortal places. But it at least helps us rediscover the politics always already within our customary (and now much derided) anthropological detachment. Before, we could marvel at if not also admire the purism with which Levi-Strauss could respond to the horrors of his time with his emphasis on the equalizing rationality of principles. We could be grateful to him for having saved us from our own stupidity (caused by using the sight-blunting concept of "the primitive" or its twin "the archaic") with a reconceptualization of history that might actually help us today come to think of today, it (i.e., help us to understand that social processes can take us into as well as out of barbarity; see Lévi-Strauss 1963a, 1963b, 1966; Sontag 1966).

Now we have to gather our utopic alterities as small possibilities collected as and where we find them. We must include looking for them in unexpected, even conventionally unacceptable places. That is, we look for places of contradiction within the blind spots of conventional wisdom, we look for good wherever people are doing it, we recognize and appreciate human innovation-self-organization, we proceed by means of the impertinent comparison. In this, we use our method and our documentary artistry to pull from the complexities of life useable principles that might be transferrable or deployable elsewhere. What we see is how charity or compassion has to be recreated through whatever political language is made available to it. An obvious example is the twinship of military deterrence and eradication campaigns. Here, I am thinking not only of the militaristic metaphors that inform approaches to public health, but also of how the quest for the everreceding goal fuels expenditure in these two areas. As Laurie Garrett observes with regard to international public health initiatives, the giving is both generous and limited (2007), while just giving the money away would be unthinkable.

There are other examples. When we think about the militarization of social life, and consider not the army as an abstract entity, but the soldier's body (Gray 1997, 2000,2003 ) and the soldier's mind we find ourselves thinking about the people who become part of a postmodern military (Moskos et al. 2000). We are obliged to see an army from its members' point of view: as a moral community (Shay 1994), as an organization whose survival depends on learning ( $\mathrm{Nagl} \mathrm{2005)}$ ), as a social form itself subject to the contradictions of blurred boundaries of sacrifice and labor (TaussigRubbo 2009b), as well as of destruction and construction (as with the expansion 
of Africa Command into building infrastructure, http://www.africom.mil/). The military becomes visible as a mode of production, and the army as an employer of precisely those people with whom ethnographers are normally in sympathy.

Inversely, by comparison, we can draw attention to war zones that are normalized into invisibility. I am thinking here of Chicago's south and west sides where the high rate of homicide was brought to public attention by the gesture of a local priest who flew the U.S. flag upside down; a "mayday!" call to the nation to attend to the community's wasted life (Pilkington 2009). Here, too, there is an originality of perspective and of social form in the community organization "CeaseFire", now known as "Cure Violence" (http://www.ceasefirechicago.org/cpvp.shtml, cureviolence.org, accessed Oct. 27, 2012).

Their approach treats the violence as a public heath matter. They use evidencebased methods for gathering information and setting targets (they are sponsored in part by a school of public health). They use hospital emergency rooms as locations for interventions, they deploy violence "interrupters" (a title and function that evokes Michel Serres's [2007] observations on the innovative potential of the parasite-the one who interrupts and redirects a flow)-people themselves past perpetrators - to try to stop the cycle of killings. They represent themselves to others as a type of social experiment in a city with a long history of political activism, vernacular and otherwise, as well as a great literature depicting how things work and how they don't.

\section{Inconclusion}

As ethnographers and ethnologists in the anthropology of medicine, we are always laboring along the confines of mortality. Here, on the ground, in the field, and by a comparative method that gives attention to local complexities, we are precisely where the praises of Foucault and the hopes of Lévi-Strauss would have us be. If we expand the language of the therapeutic, so that the core of our thinking is toward the remedy (which can only sometimes be the medicine), if we expand the concept to include not just the medical but also the legal and the political, we will find that we are better placed than most to understand the power of the single instance to change the world. I write an inconclusion because I suppose that what I'm saying is that our utopia is always in the working toward it, in the labor of love that we call a field science and its companion, a documentary art.

\section{Note on Contributor}

Christopher Davis conducted field research on the medical system of Tabwa people living along Lake Tanganyika in the Democratic Republic of the Congo. She won the 2002 Wellcome Medal for her book, Death in Abeyance. She is a regular contributor to arts programs on BBC Radios 4 and 3.

\section{References Cited}

Advertiser, $\mathrm{H}$.

2007 110th Battalion 65th Anniversary, Special Edition. Honolulu: Honolulu Advertiser. 
Agamben, G.

1998 Homo Sacer: Sovereign Power and Bare Life. Stanford: Stanford University Press. Ashforth, A.

2005 Witchcraft, Violence, and Democracy in South Africa. Chicago: University of Chicago Press.

Auge, $\mathrm{M}$

1998 A Sense for the Other: The Timeliness and Relevance of Anthropology. Stanford: Stanford University Press.

1999 An Anthropology for Contemporaneous worlds. Stanford: Stanford University Press.

Burleigh, $\mathrm{M}$

1994 Death and Deliverance: "Euthanasia" in Germany c. 1900-1945. Cambridge: Cambridge University Press.

Brown, P. L.

2009 A Doctor for Disease, a Shaman for the Soul. New York Times, http://www.nytimes.com/2009/09/20/us/20shaman.html? accessed Oct. 27, 2012.

Canguilhem, G.

1989 The Normal and the Pathological. New York: Zone.

Clifford, J., and G. E. Marcus

1986 Writing Culture: The Poetics and Politics of Ethnography. Berkeley: University of California Press.

Cunnison, I.

1951 History on the Luapula: An Essay on the Historical Notions of a Central African Tribe. Manchester: Manchester University Press on behalf of The Institute of Social Research, University of Zambia.

1956 Perpetual Kinship: A Political Institution of the Luapula Peoples. The RhodesLivingstone Journal 20:23-49.

1959 The Luapula Peoples of Northern Rhodesia: Custom and History in Tribal Politics. Manchester: Manchester University Press.

Davies, C.

2009 Assisted Suicide Guidelines Will Ease Fears, Says DPP. Guardian, http://www.guardian.co.uk/society/2009/sep/23/assisted-suicide-guidelinesdpp?INTCMP, accessed Oct. 27, 2012.

Davis, C. O.

1993 Critical Fictions: Ethnography, Identity and the Open work. Unpublished MS, Department of Anthropology, School of Oriental and African Studies.

2000 Death in Abeyance: Therapies and Illness among the Tabwa of Central Africa. Edinburgh: Edinburgh University Press.

2002 Citizenship, Gender and the Alchemy of Postmodern War. Unpublished MS, Department of Anthropology, School of Oriental and African Studies.

2007 Heart of Darkness and the Consolations of the Laboratory. Munro Lecture Series: University of Edinburgh.

de Certeau, M.

1984 The Practice of Everyday Life. Berkeley: University of California Press.

Driehaus, B.

2009 In Aftermath of Failed Execution, Ohio Governor Orders Postponement of 2 Others. New York Times, http://www.nytimes.com/2009/10/06/us/06ohio.html, accessed Oct. 27, 2012.

Fadiman, A.

1997 The Spirit Catches You and You Fall Down: A Hmong Child, Her American Doctors, and the Collision of Two Cultures. New York: Farrar, Straus, and Giroux. 
Farmer, P.

2005 Pathologies of Power: Health, Human Rights, and the New War on the Poor. Berkeley: University of California Press.

Fassin, D.

2009 Plenary Presentation: Global Public Health. Medical Anthropology at the Intersections: Celebrating 50 Years of Interdisciplinarity. Yale University, New Haven, CT. http://www.yale.edu/macmillan/smaconference/speakers.html\#fassin, accessed Oct. $27,2012$.

Foucault, $\mathrm{M}$

1970 The Order of Things: An Archaeology of the Human Sciences New York: Pantheon.

1979 Discipline and Punish: The Birth of the Prison. New York: Vintage.

Frankenberg, R.

1981 What Manchester Does Today ... ? Max Gluckman and the Social Anthropology of the Practical World. Royal Anthropological Institute of Great Britain and Ireland 45:6-8.

Garrett, L.

2007 The Challenge of Global Health. Foreign Affairs 86:14-38.

Gluckman, H. M.

1958 Analysis of a Social Situation in Modern Zululand. Manchester: Manchester University Press.

Godoy, A. S.

2002 Lynchings and the Democratization of Terror in Postwar Guatemala: Implications for Human Rights. Human Rights Quarterly 24:640-661.

2006 Popular Injustice: Violence, Community, and Law in Latin America. Stanford: Stanford University Press.

Gray, C. H.

1997 Postmodern War: The New Politics of Conflict. New York: Guilford.

2000 Cyborg Citizen: Politics in the Posthuman Age. New York: Routledge.

2003 Posthuman Soldiers in Postmodern War. Body and Society 9:215-226.

Gutmann, M., and C. Lutz

2009 Becoming Monsters in Iraq. Available at http://anthronow.com/articles/becomingmonsters-in-iraq-2, accessed Oct. 27, 2012.

Guyer, J. I.

1999 Anthropology: The Study of Social and Cultural Originality. African Sociological Review 3:23.

Haraway, D. J.

1997 Modest_Witness@Second_Millennium.FemaleMan C)_Meets_OncoMouse ${ }^{\mathrm{TM}}$ : Feminism and Technoscience. London: Routledge.

Hertz, R.,Needham, C., andNeedham, R.

1960 Death and the Right Hand. London: Cohen and West.

Jacobson, M. F.

2006 Roots Too: White Ethnic Revival in Post-Civil Rights America. Cambridge, MA: Harvard University Press.

Latour, B.

1983 Give Me a Laboratory and I Will Raise the World. In Science Observed: Perspectives on the Social Studies of Science. K. Knorr-Cetina and M. Mulkay, eds. Pp. 41-70. London: Sage.

1990 The Force and the Reason of Experiment. In Experimental Inquiries: Historical, Philosophical and Social Studies of Experimentation in Science.H. E. Le Grand, ed. Pp. 49-80. Dordrecht, the Netherlands: Kluwer. 
Le Graw, J. M., and M. A. Grodin

2002 Health Professionals and Lethal Injection Execution in the United States. Human Rights Quarterly 24:382-423.

Lévi-Strauss, C.

1963a Totemism Boston: Beacon.

1963b Structural Anthropology. New York: Basic.

1966 The Savage Mind. Chicago: University of Chicago Press.

1974 Tristes Tropiques. New York: Atheneum.

Mackey, R.

2009 Botched Execution Described as Torture. New York Times, http:// thelede.blogs.nytimes.com/2009/09/16/botched-execution-described-as-torture/, accessed Oct. 27, 2012.

Mead, $\mathrm{M}$.

1928 Coming of Age in Samoa: A Psychological Study of Primitive Youth for Western Civilisation. New York: Morrow.

Metcalf, P., and R. Huntington

1991 Celebrations of Death: The Anthropology of Mortuary Ritual. Cambridge: Cambridge University Press.

Mims, C.

1998 When We Die: What Becomes of the Body after Death. London: Robinson.

Moskos, C. C.,Williams, J. A., and D. R. Segal

2000 The Postmodern Military: Armed Forces after the Cold War. New York: Oxford University Press.

Nagl, J. A.

2005 Learning to Eat Soup with a Knife: Counterinsurgency Lessons from Malaya and Vietnam. Chicago: University of Chicago Press.

Pilkington, E.

2009 Chicago's Murdered Children. Guardian, http://www.guardian.co.uk/world/2009/ aug/11/chicago-children-murders?INTCMP, accessed Oct. 27, 2012.

Povinelli, E. A.

2009 The Child in the Broom Closet: States of Killing and Letting Die. In States of Violence: War, Capital Punishment, and Letting Die. A. Sarat and J. Culbert, eds. Pp. 169-191. Cambridge: Cambridge University Press.

Ridley, R. M., and H. F. Baker

1998 Fatal Protein: The Story of CJD, BSE, and Other Prion Diseases. Oxford: Oxford University Press.

Sarat, A.

2001 When the State Kills: Capital Punishment and the American Condition. Princeton: Princeton University Press.

Scheper-Hughes, N.

1992. Death without Weeping: The Violence of Everyday Life in Brazil. Berkeley: University of California Press.

Serres, $M$.

2007 The Parasite. Minneapolis: University of Minnesota Press.

Shay, J.

1994 Achilles in Vietnam: Combat Trauma and the Undoing of Character. New York: Atheneum.

Sontag, S.

1966 The Anthropologist as Hero: Against Interpretation, and Other Essays. New York: Farrar, Strauss and Giroux. 
Taussig-Rubbo, M.

2009a Sacrifice and Sovereignty. In States of Violence: War, Capital Punishment and Letting Die. A. Sarat and J. Culbert, eds. Pp. 83-126. Cambridge: Cambridge University Press.

2009b Outsourcing Sacrifice: The Labor of Private Military Contractors. Yale Journal of Law and Humanities 21:103-166.

Topping, A.

2009 New Assisted Suicide Guidelines to Give "Clear Advice" to Relatives. Guardian, http://www.guardian.co.uk/society/2009/sep/23/assisted-suicideguidelines-legal?INTCMP, accessed Oct. 27, 2012.

Turner, V. W.

1967 The Forest of Symbols: Aspects of Ndembu Ritual. Ithaca, NY: Cornell University Press.

Werbner, R.

1990 South-Central Africa: The Manchester School and After. In Localizing Strategies: Regional Traditions of Ethnographic Writing. R. Fardon, ed. Pp. 152-181. Edinburgh: Scottish Academic.

Williams, P. J.

1991 The Alchemy of Race and Rights. Cambridge, MA: Harvard University Press. Young, A.

1995 The Harmony of Illusions: Inventing Post-Traumatic Stress Disorder. Princeton: Princeton University Press. 